УДК 339.9:004

DOI: https://doi.org/10.37320/2415-3583/18.2

Луценко О.I.

аспірант

Киїський національний економічний університет імені Вадима Гетьмана

ORCID: https://orcid.org/0000-0003-2282-613X

\title{
ДИГІТАЛІЗАЦІЯ ЯК ОДИН $З$ ОСНОВНИХ ДРАЙВЕРІВ ТРАНСФОРМАЦІЇ ГЛОБАЛЬНОЇ ЕКОНОМІКИ: МОЖЛИВОСТІ ТА ПЕРСПЕКТИВИ УКРАЇНИ
}

У статті проаналізовано сучасний стан цифрової трансформації економіки Украӥни в умовах глобальної дигіталізації. Визначено, цчо сьогодні ичиррова трансформація є головним чинником економічного зростання та переходом на новий рівень сочіально-економічних систем. Виділено основні чинники, які перешкоджають розвитку иифрровізації української економіки. Виявлено, щчо, незважаючи на існування низки перешкод різноманітного характеру, Украӥна впевнено рухається у напрямі створення иииррової країни, активно впроваджуючи інформаиійні технологї, такі як штучний інтелект, Інтернет речей, віртуальна реальність, хмарні обчислення тощо, у всі сфери діяльності. Досліджено сучасні тендениії у формуванні та реалізації державної політики Украӥни у сфері изифровізащіï.

Ключові слова: ичифрова економіка, цүифровізація, державна політика, Інтернет, технології.

Постановка проблеми. Сьогодні зусилля урядів провідних країн світу спрямовані на впровадження засад цифрової економіки. Глобальна дигіталізація економічних відносин викликана потужним розвитком інформаційних технологій та засобів комунікації. Під впливом Четвертої промислової революції світова економіка суттєво видозмінюється, матеріальний світ поєднується 3 віртуальним і породжує нові підходи до бізнес-процесів; змінюються галузі, створюються абсолютно нові типи виробництв, а інноваційні технології, віртуальна реальність, штучний інтелект, Інтернет речей істотно змінюють методи і форми роботи та спосіб життя. Цифрові технології є рушійною силою революційних змін у більшості країн світу. Україна не стоїть осторонь такого глобального перетворення, що спонукає до аналізу та дослідження перспектив вітчизняної економіки.

Аналіз останніх досліджень і публікацій. Питання цифрової трансформації української економіки під впливом глобальної дигіталізації є вкрай актуальними і тому все частіше стають предметом дослідження багатьох науковців та практиків. Дослідженням у сфері цифровізації національної економіки присвячено праці багатьох українських учених, зокрема таких, як: О. Вишневський, С. Коляденко, К. Січкаренко, М. Руденко, Т. Юдіна, В. Фіщук, І. Тушканов, О. Голобородько, В. Опенька, В. Ляшенко та ін. Окрім того, зазначені питання активно обговорюються на всеукраїнських та міжнародних наукових заходах, аналізуються та досліджуються українськими і міжнародними інститутами й організаціями, а також розробляються та впроваджуються у межах державної політики України. Однак актуальність теми спонукає до подальших досліджень проблематики цифровізації економіки України.

Мета статті полягає в аналізі сучасного стану цифрової трансформації національної економічної галузі та визначенні тенденцій іiі розвитку.

Виклад основного матеріалу. У класичному розумінні поняття «цифрова економіка» означає діяльність, в якій основними засобами (факторами) виробництва $€$ цифрові (електронні, віртуальні) дані, як числові, так і текстові. Цифрова економіка базується на інформаційно-комунікаційних та цифрових технологіях, стрімкий розвиток та поширення яких уже сьогодні впливають на традиційну (фізично-аналогову) економіку, трансформуючи іiі від такої, що споживає ресурси, до економіки, що створює ресурси.

Цифровізація - насичення фізичного світу електронно-цифровими пристроями, засобами, системами та налагодження електронно-комунікаційного обміну між ними, що фактично уможливлює інтегральну взаємодію віртуального та фізичного, тобто створює кіберфізичний простір. Основна мета цифровізації полягає у досягненні цифрової трансформації існуючих та створенні нових галузей економіки, а також трансформації сфер життєдіяльності у нові, більш ефективні та сучасні. Такий приріст є можливим лише тоді, коли ідеї, дії, ініціативи та програми, які стосуються цифровізації, будуть інтегровані, зокрема, у національні, регіональні, галузеві стратегії і програми розвитку. Цифровізація $\epsilon$ визнаним механізмом економічного зростання завдяки здатності технологій позитивно впливати на ефективність, результативність, вартість та якість економічної, громадської та особистої діяльності [1].

Поява низки радикальних технологічних інновацій у сфері інформаційних, цифрових технологій, висока динаміка змін - усе це призвело до початку значних трансформацій в інформаційних, економічних, суспільних системах, формування нових концепції розвитку на наступні десятиліття провідними технологічно розвиненими країнами світу та визначення цих явищ і процесів як Четвертої промислової революції. В умовах Четвертої промислової революції формується концепція промислового розвитку «Індустрія 4.0» (Industry 4.0), яка стосується цифровізації виробничих процесів і передбачає технологічну еволюцію від вбудованих систем до кіберфізичних систем (CPS) [2, c. 48$]$.

Україна перебуває на ранній фазі розвитку Індустрії 4.0. У 2016 р. створено національний рух «Індустрія 4.0 в Україні», в який входить понад 100 фірм. У 2017 р. затверджено національну про- 
граму Digital Agenda Ukraine, частиною якої є Індустрія 4.0. У 2018 р. розроблено проєкт Національної стратегії «Індустрія 4.0». Ухвалено «Концепцію розвитку цифрової економіки та суспільства України на 2018-2020 роки». Асоціація підприємств промислової автоматизації України (АППАУ) з 2018 р. розвиває мережу Центрів експертизи 4.0, що базуються на провідних технічних університетах країни [3].

Важливо відзначити, що поняття цифровізації економіки в Україні принципово відрізняється від світового. В Україні поняття «цифровізація» сконцентроване винятково на створенні нових видів сервісів, що базуються на зборі та аналізі даних із різних фізичних об'єктів і не охоплює питання кардинальної зміни ситуації у виробничій системі, підходів до проєктування, виробництва, збуту та експлуатації цих фізичних об’єктів, що закладено в концепцію Індустрії 4.0. На відміну від такого підходу провідні світові промислові держави (США, Німеччина, Італія, Японія, Китай) не розглядають сервіси, що базуються на аналізі «великих даних», як самостійну та самодостатню сферу економічної діяльності. Під цифровою економікою вони розуміють саме процеси створення і використання єдиних виробничо-сервісних (або продуктово-сервісних, PSS) систем [4, с. 117-118].

Згідно зі звітом Всесвітнього економічного форуму (ВЕФ) за 2019 р., за рівнем розвитку технологій та інновацій Україна серед 100 країн світу посіла 60-е місце. За балансу двох показників - структури виробництва і рушійних сил виробництва - 70-е і 59-е місця відповідно [5].

За заявою Президента України, у 2018 р. частка IT-індустрії в українській економіці становила 4 \% ВВП. За даними Світового банку, з 2011 р. внесок IT у ВВП України збільшився з 0,6\% до 3,3\% (з \$1,1 млрд до \$2,7 млрд). Хоча Україна за рівнем розвитку IT у рази відстає від країн Східної Європи і СНД. За даними IDC (International Data Corporation), рівень витрат IT на душу населення становить \$53. У сусідніх країнах цей показник є набагато вищим: \$90-у Білорусі, $\$ 108$ - у Казахстані, \$278 - у Польщі, \$522 - у Чехії [4, с. 132].

Серед основних чинників, які перешкоджають ефективній цифровій трансформації економіки України, є: відсутність українських IT-компаній на світовому ринку, недостатність правового регулювання та державної підтримки у формуванні цифрової економіки, нерозвинутість інформаційної інфраструктури та інфраструктури цифрової довіри, низький рівень міжвідомчої взаємодії, недостатність інвестиційних ресурсів, низький рівень цифрової обізнаності населення, недостатність кваліфікованих фахівців у сфері цифрових технологій, цифровий розрив, проблеми у питаннях захисту інтелектуальної власності та захисту даних, відсутність стимулювання та розвитку інноваційного бізнесу та підприємництва тощо.

Суттєву роль у розвитку цифрової трансформації економічної галузі відіграє державна політика. Незважаючи на наявність низки блокуючих чинників, в Україні на державному рівні визнається необхідність формування цифрової економіки, а цифрові технології розглядаються як один із ключових драйверів сталого розвитку. Сьогодні в Україні здійснюється масштабна діяльність із розвитку інформаційних технологій та їх упровадження у різні сфери діяльності.

Інституційно-правове оформлення розвитку цифрової економіки в Україні розпочалося ще в 2013 р., коли Кабінет Міністрів України видав розпорядження «Про схвалення стратегії розвитку інформаційного суспільства в Україні». У 2015 р. Україна приєдналася до Декларації першого засідання міністрів «Східного партнерства СС» із питань цифрової економіки, на якому цифрова економіка була визнана сферою 3 невикористаним потенціалом як для $\mathrm{EC}$, так і для шести країн-партнерів. Важливу роль відіграє Додаток XVII 3 до Розділу IV Угоди про асоціацію, який зобов'язує Україну здійснити імплементацію низки актів СС, що встановлюють спільні норми на ринку надання електронних комунікаційних послуг, разом із директивами щодо електронних комунікацій, режимів авторських прав, захисту прав споживачів, кур'єрських служб, аудіовізуальних послуг. Україна має запровадити європейську концепцію регулювання цифрового ринку та впровадити іiї стандарти, що є однією з вимог євроспільноти задля поглиблення співробітництва [4, с. 229,231$]$.

Стартом формування політики у цифровій сфері стало прийняття Концепції розвитку цифрової економіки і суспільства України на 2018-2020 рр. Відповідно до Розпорядження Кабінету Міністрів України від 3 березня 2021 р. № 167-р «Про схвалення Концепції розвитку цифрових компетентностей та затвердження плану заходів з ії реалізації», збільшення темпів розвитку цифрових технологій, упровадження інноваційних рішень у всі сфери суспільного життя призводить до необхідності підвищення якості підготовки працівників для створення можливості модернізації економіки країни відповідно до сучасних вимог. Відсутність концептуальних засад формування державної політики у сфері розвитку цифрових навичок та цифрових компетентностей громадян не дає змоги забезпечити розвиток усіх сфер суспільного життя відповідно до сучасних вимог, процесів глобальної цифровізації економіки, сфер життєдіяльності суспільства, які відбуваються у більшості країн світу.

Важливим кроком у формуванні державної політики у сфері цифровізації стало створення у 2019 р. Комітету Верховної Ради з питань цифрової трансформації, до предметів відання якого віднесено: законодавчі засади цифровізації та цифрового суспільства в Україні; Національну та державні програми інформатизації; програми СС «Сдиний цифровий ринок» (Digital Single Market, EU4Digital) та інші програми цифрового співробітництва; інновації у сфері цифрового підприємництва, розвиток екосистеми стартапів; дослідницькі центри у сфері цифрових технологій; цифрову індустрію та телекомунікації; електронне урядування та публічні електронні послуги; електронну демократію; електронні довірчі послуги та цифрову ідентифікацію; державні інформаційно-аналітичні системи, електронний документообіг; державні інформаційні ресурси, електронні реєстри та бази даних; електронну комерцію (електронна торгівля, електронний бізнес); віртуальні активи, блокчейн та токенізацію; смарт-інфраструктуру (міста, громади тощо); розвиток сфери «відкритих даних»; радіочастотний ресурс; роз- 
виток орбітальної економіки; законодавчі засади адміністрування, функціонування та використання мережі Інтернет в Україні; кібербезпеку та кіберзахист, у тому числі у сфері критичної інфраструктури; технічний та криптографічний захист інформації; розвиток цифрових компетентностей, цифрові права [6].

Не менш вагомою подією у напрямі розвитку цифрової держави стало створення у 2019 р. Міністерства цифрової трансформації України. Сьогодні воно $\epsilon$ головним органом у системі центральних органів виконавчої влади, що забезпечує формування та реалізацію державної політики: у сферах цифровізації, цифрового розвитку, цифрової економіки, цифрових інновацій та технологій, електронного урядування та електронної демократії, розвитку інформаційного суспільства, інформатизації; у сфері впровадження електронного документообігу; у сфері розвитку цифрових навичок та цифрових прав громадян; у сферах відкритих даних, розвитку національних електронних інформаційних ресурсів та інтероперабельності, розвитку інфраструктури широкосмугового доступу до Інтернету та телекомунікацій, електронної комерції та бізнесу; у сфері надання електронних та адміністративних послуг; у сферах електронних довірчих послуг та електронної ідентифікації; у сфері розвитку IT-індустрії [7].

У контексті досліджуваної тематики гостро постає питання законодавчого відображення цифрової трансформації взагалі та цифровізації економіки зокрема. Основними нормативно-правовими актами щодо врегулювання зазначеної сфери є: Указ Президента України «Про Цілі сталого розвитку України на період до 2030 року» від 30 вересня 2019 р. № 722/2019; Розпорядження Кабінету Міністрів України «Про схвалення Концепції розвитку цифрової економіки та суспільства України на 2018-2020 рр. та затвердження плану заходів щодо іï реалізації» від 17 січня 2018 р. № 67-p; Меморандум про створення Української національної цифрової коаліції «Коаліція цифрової трансформації» від 5 вересня 2019 р.; Постанова Кабінету Міністрів України «Про затвердження Державної стратегії регіонального розвитку на 2021-2027 рр.» від 5 серпня 2020 р. № 695.

Зокрема, відповідно до оперативної цілі № 4 «Розвиток інфраструктури та цифрова трансформація регіонів» Державної стратегії регіонального розвитку на 2021-2027 pp., серед інших завдань за напрямом «Цифрова трансформація регіонів» у сфері цифрових комунікацій та цифрової інфраструктури основними є: забезпечення пріоритетного впровадження та розвиток системи електронного документообігу, розвиток платформ та офіційних порталів органів місцевого самоврядування, забезпечення переведення пріоритетних публічних послуг в електронну форму, забезпечення безперешкодного доступу до високошвидкісного Інтернету всіх населених пунктів (насамперед сільських та малих міст), створення умов для ринкової конкуренції між провайдерами, забезпечення підключення до грудня 2023 р. 100\% державних установ та соціальних закладів до широкосмугового Інтернету зі швидкістю від 100 Мбіт/с, запровадження у приміщеннях державних органів, соціальних закладів та комунальних установ відкритих Wi-Fi-зон для вільного під’єднання до Інтернету відвідувачами та працівниками, забезпечення покриття мобільним зв'язком міжнародних державних транспортних коридорів, забезпечення міжнародних транспортних переходів, аеропортів, автомобільних та залізничних вокзалів доступом до Інтернету та облаштування відкритих Wi-Fi-зон для відвідувачів та персоналу, сприяння операторам в оформленні дозволів на розміщення телекомунікаційного обладнання, прокладення мереж, відведення земельних ділянок для розміщення радіовеж тощо, запровадження механізмів зменшення витрат операторів у регіонах із низьким рівнем покриття мобільним зв'язком та Інтернетом, забезпечення цільового фінансування поширення Інтернету в державних установах, соціальних закладах, розміщених у віддалених населених пунктах або за їх межами [8].

Окремі питання цифровізації регулюються іншими законодавчими актами, серед яких: Закон України «Про електронну комерцію» від 3 вересня 2015 р. № 675-VIII; Закон України «Про електронні документи та електронний документообіг» від 22 травня 2003 р. № 851-IV; Закон України «Про основні засади забезпечення кібербезпеки України» від 5 жовтня 2017 р. № 2163-VIII; Закон України «Про електронні довірчі послуги» від 5 жовтня 2017 р. № 2155-VIII; Постанова Кабінету Міністрів України «Деякі питання цифрового розвитку» від 30 січня 2019 р. № 56 тощо.

Підтвердженням спрямованості державної політики у напрямі цифрової трансформації стало підписання Президентом України 31 травня 2021 р. під час участі у Всеукраїнському форумі «Україна 30 . Освіта і наука» Указу № 217/2021 «Питання проєкту «Президентський університет».

Проєкт «Президентський університет» розглядається як сучасна освітня платформа, що забезпечить доступність громадян України до інноваційних освітніх моделей та стратегій навчання, ефективного використання ресурсів освітньої інфраструктури та просторів коворкінгу з реалізації освітніх, наукових i творчих проєктів. Передбачається, що освітній процес у Президентському університеті будуватиметься на основі спеціальностей, що становлять основу шостого технологічного укладу, які формують науково-технічний прогрес i дають змогу підготувати професіоналів вищого рівня. Це інформаційні технології, кібербезпека і штучний інтелект, нанотехнологіï, аерокосмічні, енергетичні технології, біотехнології і науки про здоров'я, глобалізація та міжнародні комунікації [9].

Висновки. Постійне вдосконалення цифрових технологій та їх глобальна інтеграція у всі сфери життєдіяльності суспільства кардинально змінюють світову економіку, а тому пріоритетним шляхом розвитку економіки України є активне впровадження цифрових інфраструктур, останніх технологій та інновацій у всі галузі національної економіки. Сьогодні ефективна державна політика України у сфері цифровізації економіки створює сприятливі обставини для розвитку цифрової економічної інфраструктури та умови для iii динамічної розбудови. Окрім зазначеного, в Україні ведеться активна діяльність щодо врегулювання питань цифровізації на законодавчому рівні, розвивається мережа хабів цифрової освіти для населення, 
здійснюється масштабне переведення державних послуг в онлайн-режим, успішно втілюється у життя концепція «Держава у смартфоні». 3 огляду на зазна- чене, можна стверджувати, що Україна впевнено реалізує ініціативи, спрямовані на повну цифровізацію не лише економіки, а й усіх сфер діяльності.

\section{Список використаних джерел:}

1. Про схвалення Концепції розвитку цифрової економіки та суспільства України на 2018-2020 роки та затвердження плану заходів щодо іiі реалізації : Розпорядження Кабінету Міністрів України від 17 січня 2018 p. № 67-p. URL: https://zakon.rada.gov.ua/laws/show/67-2018-\%D1\%80\#n13 (дата звернення: 24.05.2021).

2. Правове забезпечення віртуалізації інфраструктури національної економіки України : монографія / О.В. Шаповалова та ін. Харків : НДІ прав. забезп. інновац. розвитку НАПрН України, 2019. 184 с.

3. Юрчак О. 5 років Індустрії 4.0 - де Україна? URL: https://investgazeta.ua/blogs/5-rokivindustriji-4-0-de-ukrajina (дата звернення: 26.05.2021).

4. Пищуліна О. Цифрова економіка: тренди, ризики та соціальні детермінанти. Київ : Центр Разумкова ; Заповіт, 2020.274 с.

5. The Global Competitiveness Report 2019. World Economic Forum. URL: http://www3.weforum.org/docs/WEF_TheGlobalCo mpetitivenessReport2019.pdf (дата звернення: 26.05.2021).

6. Про перелік, кількісний склад і предмети відання комітетів Верховної Ради України дев'ятого скликання : Постанова Верховної Ради України від 29 серпня 2019 р. № 19-IX. URL: https://zakon.rada.gov.ua/laws/show/19-20\#Техt (дата звернення: 29.05.2021).

7. Питання Міністерства цифрової трансформації : Постанова Кабінету Міністрів України від 18 вересня 2019 р. № 856. URL: https://zakon.rada.gov.ua/laws/show/856-2019-\%D0\%BF\#Text (дата звернення: 29.05.2021).

8. Про затвердження Державної стратегії регіонального розвитку на 2021-2027 роки : Постанова Кабінету Міністрів України від 5 серпня 2020 р. № 695. URL: https://zakon.rada.gov.ua/laws/show/695-2020-\%D0\%BF\#Техt (дата звернення: 03.06.2021).

9. Питання проєкту «Президентський університет» : Указ Президента України від 31 травня 2021 р. № 217/2021. URL: https://www.president.gov.ua/documents/2172021-39029 (дата звернення: 07.06.2021).

\section{References:}

1. Kabinet Ministriv Ukrainy (2018) Rozporiadzhennia «Pro skhvalennia Kontseptsii rozvytku tsyfrovoi ekonomiky ta suspilstva Ukrainy na 2018-2020 roky ta zatverdzhennia planu zakhodiv shchodo yii realizatsii» [Order of the Cabinet of Ministers of Ukraine «On Approval of the Concept of development of the digital economy and society of Ukraine for 2018-2020 and approval of the action plan for its implementation»]. Available at: https://zakon.rada.gov.ua/laws/show/67-2018-\%D1\%80\#n13 (accessed 24 May 2021).

2. Shapovalova O.V. (Eds.) (2019) Pravove zabezpechennia virtualizatsii infrastruktury natsionalnoi ekonomiky Ukrainy [Legal support of virtualization of the infrastructure of the national economy of Ukraine]. Kharkiv: NDI prav. zabezp. innovats. rozvytku NAPrN Ukrainy.

3. Yurchak O. (2019) 5 rokiv Industrii 4.0 - de Ukraina? [5 years of Industry 4.0 - where is Ukraine?]. Available at: https://investgazeta.ua/blogs/5-rokivindustriji-4-0-de-ukrajina (accessed 26 May 2021).

4. Pyshchulina O. (2020) Tsyfrova ekonomika: trendy, ryzyky ta sotsialni determinanty [Digital economy: trends, risks and social determinants]. Kyiv: Tsentr Razumkova: Zapovit.

5. The Global Competitiveness Report 2019. World Economic Forum. Available at: http://www3.weforum.org/docs/WEF_TheGlo balCompetitivenessReport2019.pdf (accessed 26 May 2021).

6. Verkhovna Rada Ukrainy (2019) Postanova «Pro perelik, kilkisnyi sklad i predmety vidannia komitetiv Verkhovnoi Rady Ukrainy deviatoho sklykannia» [Resolution of the Verkhovna Rada of Ukraine «On the list, quantitative composition and subjects of the committees of the Verkhovna Rada of Ukraine of the ninth convocation»]. Available at: https://zakon.rada.gov.ua/laws/ show/19-20\#Text (accessed 29 May 2021).

7. Kabinet Ministriv Ukrainy (2019) Postanova «Pytannia Ministerstva tsyfrovoi transformatsii» [Resolution of the Cabinet of Ministers of Ukraine «Issues of the Ministry of Digital Transformation»]. Available at: https://zakon.rada.gov.ua/laws/show/856-2019$\%$ D0\%BF\#Text (accessed 29 May 2021).

8. Kabinet Ministriv Ukrainy (2020) Postanova «Pro zatverdzhennia Derzhavnoi stratehii rehionalnoho rozvytku na 2021-2027 roky» [Resolution of the Cabinet of Ministers of Ukraine «On approval of the State Strategy for Regional Development for 2021-2027»]. Available at: https://zakon.rada.gov.ua/laws/show/695-2020-\%D0\%BF\#Text (accessed 03 June 2021).

9. Prezydent Ukrainy (2021) Ukaz «Pytannia proektu «Prezydentskyi universytet» [Decree of the President of Ukraine «Issues of the project «Presidential University»]. Available at: https://www.president.gov.ua/documents/2172021-39029 (accessed 07 June 2021 ).

Lutsenko Oleksandr National Economic University named after Vadym Hetman

\section{DIGITALIZATION AS ONE OF THE MAIN DRIVERS OF TRANSFORMATION OF THE GLOBAL ECONOMY: OPPORTUNITIES AND PROSPECTS OF UKRAINE}

The article analyzes the current state and main problems of Ukraine's economic development in the conditions of global transformation processes related to digitalization. The concept of digital economy is revealed. The relevance of the studied issues is due to the fact that the development of digital economy and cyberphysical systems is a priority area of global technical and technological transformation. In recent years, the world's leading countries are moving to a new technological system known as Industry 4.0. A characteristic feature of these changes is the rapid digitalization of the economy, which is rapidly and radically changing people, production, the state and society. The purpose of the 
study of the outlined topics is to study the current state of the level of digital transformation of the economy in Ukraine, as well as the analysis of the obtained data in order to outline the future prospects of this industry. For the most part, the research methods were reduced to the analysis of the current state of digitalization in Ukraine, in particular, the state policy in this area was subject to detailed analysis, because the affective and effective implementation of any transformation processes requires support from the state. Based on the analysis, it was found that today Ukraine has a sufficient number of barriers to active digitalization, especially in the economic sector, which leads to a slow transition to a new technological level. At the same time, it was found that the pace of public policy in this area is aimed at steady growth. In particular, active work is being done to create special departmental bodies and departments, as well as to regulate and stimulate issues of digital transformation. Issues of digitalization are increasingly becoming the subject of research by scientists and the main issues for discussion by the scientific community at international, national, interagency and departmental events. The practical value of the article lies in the need for constant research and development of the outlined issues, because for the Ukrainian economy digitalization trends are associated with serious challenges, as the formation of the digital economy becomes for Ukraine its national security and competitiveness in the world market, as well as issues of the level and quality of life of the population of Ukraine.

Key words: digital economy, digitalization, state policy, Internet, technologies.

JEL classification: $\mathrm{O} 16, \mathrm{O} 33, \mathrm{O} 38$ 